\title{
Developing Learning Media Based on PowToon Application for Teaching English for Nurses
}

\author{
Putu Rusanti*, Kadek Maya Cyntia Dewi \\ DIV Nursing Anesthesiologist, Faculty of Health, Institute of Technology and Health Bali \\ *Corresponding Author. Email: rusanti.putu@gmail.com
}

\begin{abstract}
This research aimed to identify the need analysis of learning English for Nurses (EFN) for nursing students and to develop learning media by using powtoon application in teaching English for Nurses. The research employed research and development (R\&D) design. It was used Sugiyono model consisted of potential and problem, data collection, product design, design validation, design revision, product testing, product revision, and massive production. The data were collected through questionnaires and interview. The learning videos were validated by expert judges and were also done field testing to the 42 nursing students. The data were analyzed descriptively qualitative. The result of the research showed that 1) $64.5 \%$ of the students would like to combine the material between general English and specific topics about nursing, 2) The developed learning video consisted of some parts such as opening, learning objectives, content, conversation, vocabularies, and closing. The result of expert judges both in media and material were $87.5 \%$ and $93.5 \%$ which were categorized as excellent materials. It is expected that the learning video can be applied in teaching and learning process.
\end{abstract}

\section{Article History}

Received: 09-12-2020

Revised: 04-02-2021

Accepted: 20-04-2021

Published: 07-06-2021

\section{Key Words}

Learning Media,

PowToon, English for

Nurses.

How to Cite: Rusanti, P., \& Dewi, K. (2021). Developing Learning Media Based on PowToon Application for Teaching English for Nurses. Jurnal Kependidikan: Jurnal Hasil Penelitian dan Kajian Kepustakaan di Bidang Pendidikan, Pengajaran dan Pembelajaran, 7(2), 270-280. doi:https://doi.org/10.33394/jk.v7i2.3217

https://doi.org/10.33394/jk.v7i2.3217

This is an open-access article under the CC-BY-SA License.

\section{Introduction}

The global competition requires people to improve their specific skills. It is supported by the trend of globalization 4.0 which makes the advance utilization of technology. In the education, the improvement of the technology can be applied in the developing of learning media. The existence of learning media has an important role in the teaching and learning process. The use of innovative and interesting learning media can stimulate students' interest and willingness to learn in the classroom. According to Falahudin (2014) learning media also improve students' motivation and encourage them to be active during the learning process. Looking at the importance of learning media, the teacher needs to be creative and innovative in designing learning media so the materials can be understood by students.

English for non-English students is called ESP (English for Specific Purposes). English for Spesific Purpose is an English teaching approach where the things taught and the teaching methods are based on the reasons why students want to learn English (Hutchinson \& Waters, 2008). English For Specific Purposes has a different approach and assumptions to General English. The objective of learning ESP is the students are able to communicate English as well as their purposes for example English for Business, English for Nurses, and English for Law. Those subjects have different purposes and so do the terminologies. The students will learn specific English terminologies according to the purpose of English usage. The students who learn English for nurses will have different material with students who learn English for business. It is important for the lecturer to develop appropriate learning media. 
One of the ESP subject is English for Nurses (EFN). This subject is taught for nursing students. According to Daar, Ndorang \& Golo (2016), the purpose of EFN courses is students are able to acquire the concept of English in nursing and able to communicate English in the provision of nursing care. Therefore, communication ability in English is absolutely necessary due to the globalization era. In this era, the patients who visit the hospital can be from different countries. Thus, nursing students should be able to communicate English well in giving nursing care.

English for Nurses subject is taught in the third semester. The students learn EFN through practicing more and understanding new terminologies related to nurses. However, the English materials are limited. Based on the observation conducted in EFN class, students of Institute of Technology and Health Bali used one book adapted from abroad. This book has weaknesses such as it provide less exercise to practice English and it doesn't include grammar in teaching English. The students have limited references for them in learning ESP. Therefore, it needs to have a supplementary material to improve students' knowledge. This supplementary material provide more detail informations regarding to the the materials.

Supplementary material was created in accordance with technology development. Nowadays, the teaching and learning process are based on the ICT-based. One of the examples of using ICT in teaching and learning process is through video. Using video as learning media can make the students easier to understand the messages and information conveyed in the learning process. The strength of using video as a learning media is the students can access easier. Moreover, video is interesting since it shows motion of picture and the students can learn through watching and listening.

One of the interesting and modern learning media based on information and communication technology is Powtoon. Powtoon is an online web application used to create animated cartoons or presentation videos in an easy way (Graham, 2015). Powtoon applications are generally the same as Power Point which is used to create presentation media. However, the Powtoon app has the advantage of being able to create more lively handwriting animations, cartoon animations, and transition effects as well as very easy timeline settings (Nurdiansyah, Faisal, \& Sulkipani, 2018).

Some of the researches which related to this study also explained. Arifin (2018) developed research entitled Developing media based on video animation by using ADDIE in blended learning. The purpose of learning through video was the students could learn by themselves. In this research, the researcher used shift class students as the subject of the study which means the class had less meeting with the lecturer. The result of the research showed that video animation can courage the students to do self-study with interesting way of teaching. It is relevant with this study because its purpose makes nursing students can do selfstudy so they can learn by themselves by using video.

Henu (2017) also stated that the use of learning media PowToon can improve the students' learning outcome. There were differences learning outcome of control group and experiment group in social studies subject of SMP Negeri 15 Semarang. By giving PowToon, the students were given material in audiovisual with an interesting animation. So, the students will not be bored in listening to the teacher's explanation. The role of developing PowToon in teaching is as the alternative media for the teacher to attract the students' attention through video.

Nurdiansyah (2019) also developed learning media by using PowToon in Civic subject. This research also developed PowToon media for the university students. The result of this research was the students were more active in the classroom during teaching and learning process by using PowToon media. It showed that the activity can be varied by the 
lecturer so the students participated well in the classroom. Based on the research reviewed, PowToon were suitable used as the learning media in all grades. However, there are no researchers who developed PowToon as learning media in English for Nurses subject. Since it belongs to ESP, the learning media is needed to develop in order to improve the students' outcome in learning English for Nurses.

The purpose of the research is (1) to identify the need analysis of learning video in teaching English for Nurses (EFN), (2) to design and develop learning video in teaching English for Nurses (EFN) by using PowToon. The urgency of this study is the needs of an innovative learning media as an additional material of English for Nurses (EFN) by using PowToon. It is caused by the resources for learning EFN are still limited so the additional materials are needed to support the learning process.

\section{Research Method}

The research employed research and development (R\&D) design. It focuses on producing a certain product and also to assess the effectiveness of the product. The research and development contained of ten steps such as potential and problem, data collection, product design, design validation, design revision, product testing, product revision, empirical testing, product revision, and massive production (Sugiyono, 2014). This study was conducted in Institute of Technology and Health Bali. There were 42 students recruited as the respondents of the research. Problem identification was done through the process of questionnaire, interview, and document analysis. The analysed documents were syllabus and existing material. The questionnaires were given to the English lecturer who teach English for Nurses (EFN) subject and also the students to know their problems in learning EFN. Besides, the interview was also conducted to the students and some students to get the data.

The learning videos were validated by validators or expert judges. The purpose of the validation was to gain the evaluation comments and advices as well as input on the assessment profiles. The expert judges were given rubrics based on criteria of good materials by Thomlinson (1998). There are two expert judges used in this research such as expert judges in media and expert judges in material. Then, the videos were also validated by the students by doing small field testing. The quality of the product was obtained from expert judges and data from the field testing. Then, the revision was done based on the result of the expert judgments. The PowToon-based learning video will be declared valid if it gets a validation score based on the criteria and category of content validity $>60 \%$ (Kafah, Nulhakim, \& Pamungkas, 2020). The result of the expert judges will be categorized based on the table of interpretation of eligibility criteria.

\begin{tabular}{cc} 
Table 1. Criteria and Category of Content Validity \\
\hline Qualitative Value & Score \\
\hline $0 \%<\mathrm{NP} \_0 \%$ & Poor material \\
$20 \%<\mathrm{NP} \leq 40 \%$ & Low material \\
$40 \%<\mathrm{NP} \leq 60 \%$ & Average material \\
$60 \%<\mathrm{NP} \unlhd 80 \%$ & High material \\
$80 \%<\mathrm{NP} \unlhd 100 \%$ & Excellent material
\end{tabular}

The data were analyzed in descriptively qualitative. Miles and Huberman (2014) stated there were three activities on data analysis. Those were data reduction, data display, and conclusion drawing or verification. Data reduction referred to the process of selecting, focusing, simplifying, and transforming the raw data. Data display provided an organized, compressed assembly of information that permits conclusion drawing. A data display could be displayed in the form of table, chart, diagram, pictogram, that provide a new way of 
arranging and thinking about the more textually embedded data. The last step was conclusion drawing or verification. It included the researcher interpretation on the result of the data have been collected.

\section{Finding and Discussion}

\section{Need Analysis of Learning Material}

English for Nurse is one of the subjects had by the nursing students in third semester. This subject employed the students to use English while learning the nursing terminologies. This study used Research and Development (R\&D) model developed by Sugiyono. The first step was finding potential and problem faced by nursing students and the lecturer. According to Puspitarini, Akhyar, \& Djono, (2019) the purpose of exploring needs analysis was to know the potential of teaching materials and identify the problems faced by students and lecturers in learning EFN. The potential and problem were obtained through questionnaire and interview. Based on the interview conducted to the lecturer, the potential that they had was a textbook for teaching. The students also owned the textbook used in the teaching and learning process. The lecturer gave assignment or activity from the textbook. According to Harmer (2007) an important aspect of a learning book was being able to invite students to understand the content of material they are going to study. Therefore, the lecturer used text book to make the students understand on the subject given. However, the students sometime were bored in learning through textbook. It needed another learning media which can encourage them to speak up and active in the classroom.

Potential and problem analysis was done by using questionnaire. The questionnaire was given to 42 nursing students who got English for Nurse (EFN) subject. The purpose was to know the needs of the students in learning so that it can be developed in to a learning media. The result of the data could be seen in the table 2 .

Table 2. The Material Needed by the Students

\begin{tabular}{clcc}
\hline No & Needs & Respondents & Percentage \\
\hline 1 & General English & 3 & $7.1 \%$ \\
2 & Specific topic about nursing & 12 & $28.6 \%$ \\
3 & General English and specific topic & 27 & $64.3 \%$
\end{tabular}

about nursing

Table 2 showed that there $64.3 \%$ of students needed general topics and specific topics about nursing. It showed that besides learning about nursing terminologies, the students also needed to develop their English skill such as listening, reading, writing and speaking. The purpose of learning ESP was the use of English which places more emphasis on their special skills, namely the field of nursing. Then, the learning media were developed in the form of explanation and instructional videos. The students got explanation on nursing terminologies meanwhile instructional means the students did the instructional activities to practice English in the classroom. The learning media developed was in terms of video. It could be seen from the result of questionnaire in table 3 .

Table 3. Students' Willingness to Learn through Video

\begin{tabular}{llcc}
\hline No & Question & Respondents & Percentage \\
\hline 1 & $\begin{array}{l}\text { Are you interested in learning EFN through } \\
\text { video? }\end{array}$ & 42 & $100 \%$
\end{tabular}

Table 3 showed that 42 students were happy and interested in learning EFN through video. It implied that the students need teaching and learning media through computer based. The use of technology must also be supported by an interesting learning strategy. Nowadays, teaching and learning media through technology had been developed in order to encourage the 
students to use technology in their daily life. One of them was by using video animation. According to Basriyah and Sulisworo (2018) the use of video animation made the teaching and learning process become more interesting, interactive, and was able to motivate the students in understanding the materials.

The analysis of materials was also conducted in order to know which topic they wanted to develop into a video. In English for Nurses (EFN) subjects, there were 9 topics given to the students during a semester. The results of the student's needs for the topic to be developed into a video could be seen in table 4 .

Table 4. The Result of Material Analysis which is developed into Video

\begin{tabular}{clcc}
\hline No & \multicolumn{1}{c}{ Topics } & Frequency & Percentage \\
\hline 1 & Asking and showing rooms in hospital & 21 & $50.0 \%$ \\
2 & Explaining medicine & 39 & $92.8 \%$ \\
3 & Diagnosing Health Problem & 25 & $59.5 \%$ \\
4 & Part of human body & 16 & $38.1 \%$ \\
5 & Checking vital sign & 30 & $71.4 \%$ \\
6 & Range of Motion & 37 & $88.1 \%$ \\
7 & Medical Equipment & 33 & $78.6 \%$ \\
8 & Asking and telling about measurement & 20 & $47.6 \%$ \\
9 & Crutch Walking & 22 & $52.4 \%$
\end{tabular}

Table 4 showed the topics needed by the students to be developed into learning video. There were four topics which had high percentage such as explaining medication $(92.8 \%)$, medical equipment (78.6\%), checking vital sign (71.4\%) and range of motion (88.1\%). Those four topics were chosen to be developed into learning video. Based on the interview done, the lecturer stated that those topics were suitable to be developed as learning video. It was caused by those topics were contained of nursing theories and general English. Those materials should be combined well into a video. In addition, the lecturer stated that it was hard to find out learning video which appropriate with students' abilities.

Based on the potential and problem analysis, it was needed to develop a supplementary learning media such as by using video. It was accordance with the needs and students' abilities. This learning video aimed to make the students motivated and be interested in learning English for Nurses. Rambe \& Saragih (2016) stated that video is an interactive way to stimulate the students to learn something. It emphasized on the use of audiovisual media such as video, film, and slide can help teacher in teaching and learning process to achieve the goal of learning.

\section{Developing Learning Video through PowToon}

The next step after knowing potential and problem was developing the product. There were four videos were developed based on the result of potential and problem analysis. Those learning videos were created by using PowToon. This application was chosen because it has many features. PowToon provided more animation rather than other applications. Those animations could be set easily by the users to give the illustration of the materials (Awalia, Pamungkas, \& Alamsyah, 2019). It could be managed based on the needs of the users. In here, the developed materials contained of some parts such as opening, learning objectives, contents, conversation, vocabularies, and closing.

1) Opening/ Greeting

The videos were started with greeting and asking the students readiness to follow the materials. The first slide was made as interesting as possible in order to attract the students' attention. It considered the colors and animation which made the users interested in watching the video. Moreover, the background on the video was hospital 
which made the feeling of watching video was about medical. The opening of the video can be seen on picture 1 .

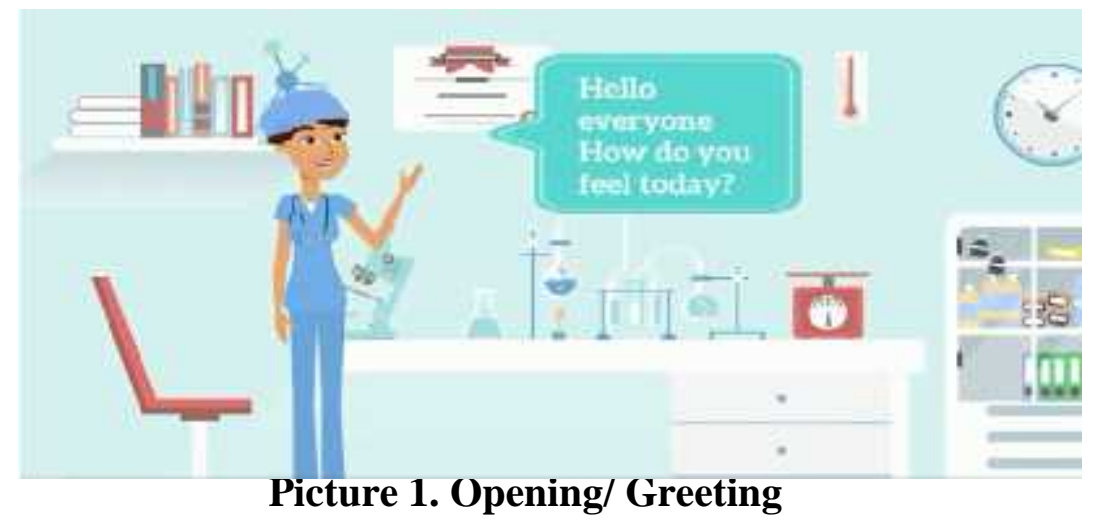

2) Learning Objectives

\section{Picture 1. Opening/ Greeting}

One of the criteria of good material is showing learning objectives. In this video, the learning objectives were showed to the students so that they knew the goals after watching it. Picture 2 showed that a nurse explained the learning objectives of the lesson. The learning objectives were taken from the syllabus.

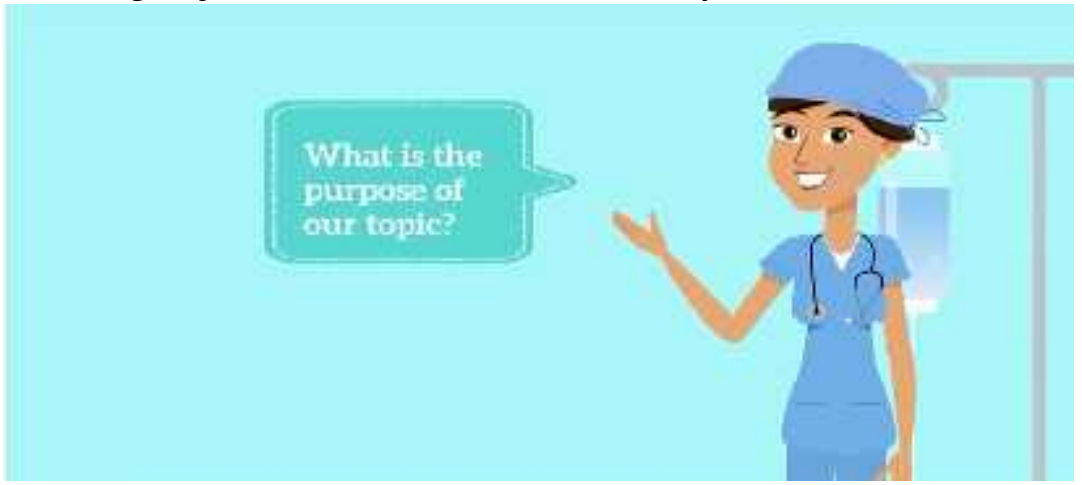

Picture 2. Learning Objectives

3) Content

In here, the video explained about the main topic that would be discussed. The topics were based on the result of potential and problem analysis. The materials were supported with images, audio and text so that students could listen and read the text clearly. They also learned listening as well as reading the materials. The intonation and duration of the audio were also adjusted so that the students understand the information. In addition, expressions used in doing conversation were also displayed. The material can be seen in picture 3 .

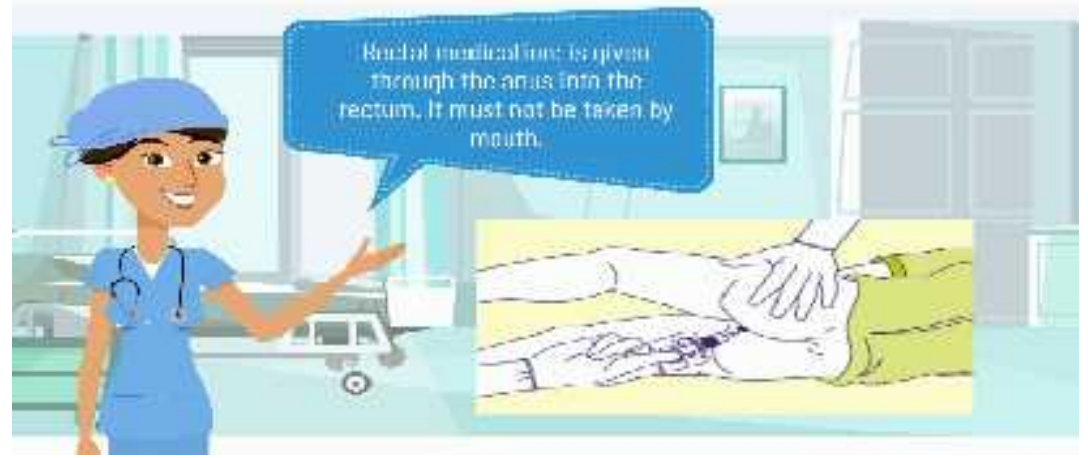

Picture 3. Content Material

Jurnal Kependidikan Vol. 7, No. 2 : June 2021 
4) Conversation

The next part in the video is conversation. Here, students learned the use of nursing terminologies in the form of conversation. It showed the example how to use those expressions in daily life. The students also can practice it in the classroom. The lecturer can create innovative learning strategies to use English in the classroom. The example of conversation in the video can be seen in picture 4.

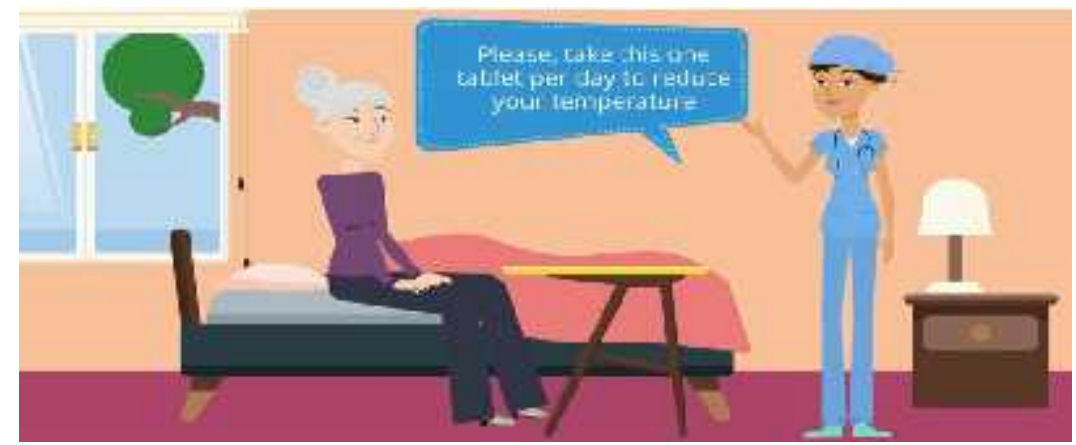

5) Vocabularies

Picture 4. Conversation

The video also aimed to improve students' vocabularies. After giving conversation, the vocabularies were showed in order to make the students understand the meaning of the new words. Some students were unfamiliar with nursing terminologies in English. It would help her to convey the meaning of the words. It can be seen in picture 5 .

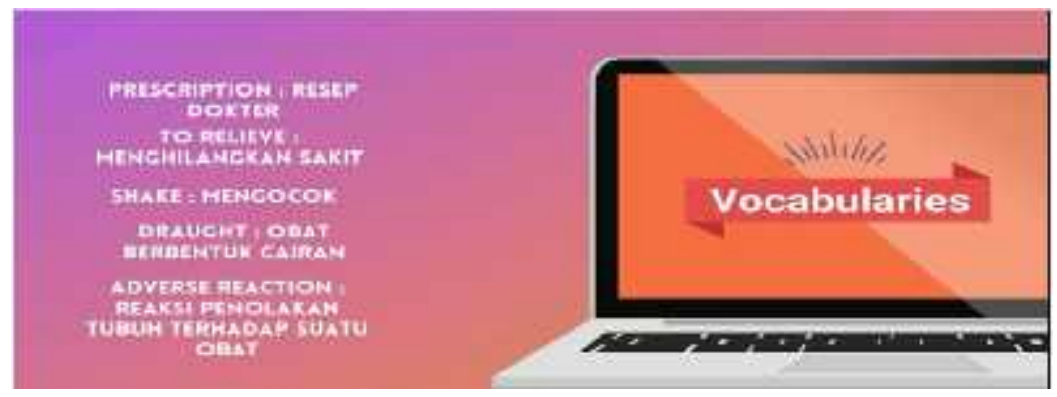

Picture 5. Vocabularies

6) Closing

At the end of the video, it contained motivational sentences for learning EFN. It aimed to encourage the students to be interested in this subject. When the students were happy to learn, they would accept the entire material well. It also explained the importance of learning EFN for the future. At the end, it was closed by saying goodbye. The example can be seen in picture 6 .

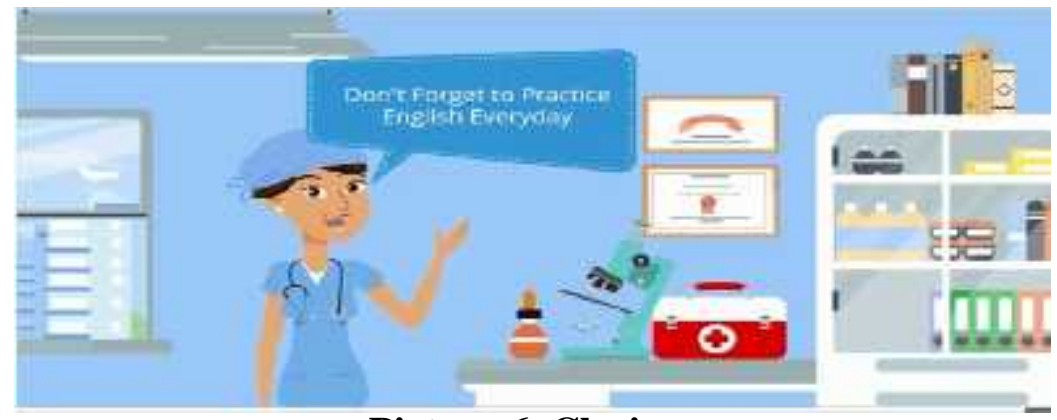

Picture 6. Closing 
The next stage is finding the validity and reliability of the product. The purpose of validity is intended to determine the accuracy and accuracy of measuring instrument in carrying out its function (Rahmah et al, 2020). The quality of the developed materials was validated by expert judges and user judges. The expert judges were the lecturers who were expert in educational sides. The expert judges were given rubric appropriateness based on good material by Thomlinson (1998). The result of the expert judge in media can be showed in table 5 .

Table 5. Result of Expert Judge in Media

\begin{tabular}{llc}
\hline No & Topics & Percentage \\
\hline 1 & Explaining Medication & $86.0 \%$ \\
\hline 2 & Checking Vital Sign & $86.0 \%$ \\
\hline 3 & Medical Equipment & $88.0 \%$ \\
\hline 4 & Range of Motion & $90.0 \%$ \\
\hline & Mean & $\mathbf{8 7 . 5 \%}$ \\
\hline
\end{tabular}

The expert judge stated that choosing PowToon as learning video is a good choice. The result of expert judge was $87.5 \%$ which categorized as excellent material. It can be said that the learning video can be used for the students in learning. The judge stated that the color, background and typography were suitable for the students. The advantages of using PowToon application is the users can insert pictures, video, voice, and the users can use tutorial page which provides simple steps to operate the application (Pangestu \& Wafa, 2018). It will make the users easier to use this application. According to Budiyono (2020) the teachers should develop their own media since they know the problems faced by the students. Knowing the characteristics, the needs of the students, learning objectives can be used to develop a suitable material for them. It will lead to an effective teaching and learning process.

The appropriateness of the materials and the syllabus were also examined by the expert. The expert judges analyze the content of the learning video. The result of the expert judge can be showed in table 6 .

Table 6. The Result of Expert Judge in Material

\begin{tabular}{llc}
\hline No & Topics & Percentage \\
\hline 1 & Explaining Medication & $93.0 \%$ \\
\hline 2 & Checking Vital Sign & $94.0 \%$ \\
\hline 3 & Medical Equipment & $92.0 \%$ \\
\hline 4 & Range of Motion & $95.0 \%$ \\
\hline & Mean & $\mathbf{9 3 . 5 \%}$ \\
\hline
\end{tabular}

Table 6 showed the result of expert judge in material was 93.5\%. This could be categorized as excellent material. The expert looked at the appropriateness of the materials with the syllabus. The developed materials should be accordance with the learning objectives stated in the syllabus (Puspitarini, Akhyar, \& Djono, 2019). The expert judge stated that the content of the materials has combined between nursing knowledge and general English. Those two parts should be balance given to the students since they need to improve their English skill and nursing terminologies too.

The quality of the material was also taken from doing field testing to the students. The field testing was done to 42 nursing students at Institute of Technology and Health Bali. The field testing was done through online class since it was pandemic. They were given 10 questions related to the learning videos. There were $52.4 \%$ of the students agreed that videos can facilitate the material delivered to the students. It means that video by using PowToon is one of the learning media which can motivate students to learn. According to Fajar (2017) 
PowToon is a software as a service which can be accessed via online and can be used as a learning media in giving presentation to help the teacher during teaching and learning process. Since the function as a presentation, the students can understand the material through the explanation and the picture given on the video. Besides giving attractive images, video can increase students' imagination and practice listening skills.

In terms of typography, there were $54.8 \%$ of the students strongly agreed that the font size, colors, and images on the materials were appropriate and understandable. In terms of language, there were $83.3 \%$ of the students strongly agreed that the language instructions used in the video were easy to understand. A clear instruction will help the students when they were learning by themselves. According to Sidik and Winata (2016), the effective instruction used in teaching and learning process is direct instruction which means it focuses on instruction given by teacher to students directly, systematically, and clearly. Moreover, $59.5 \%$ of the students strongly agreed that the learning video can be accessed easily. Besides giving a good material, learning video must be easily accessed for the students. It is caused by the file was in mp4 format and uploaded in YouTube so the learning video can be watched and download freely by the students. It is supported by Herawati, Sulisworo, \& Fayanto (2019) video-based learning media is very easy to apply because it does not require special software. If there is an important material, the students can press the 'pause' button on the video and read the text on the video. It makes the students easier to learn the material. Daniati, Ismanto \& Luhsasi (2020) stated that the implementation of e-learning model in classroom could improve the students' outcome. The research showed that the result of cycle I was $74.11 \%$ and cycle II was $80.11 \%$. This action research could be said successful when the students' motivation was $75 \%-100 \%$. From the result, it showed that e-learning could improve students' outcome.

\section{Conclusion}

Based on the finding and discussion, the potential and problem analysis found that the learning media used by the lecturer and students in teaching and learning process was a textbook. There were $64.5 \%$ of the students would like to combine the material between general English and specific topics about nursing. There were 4 topics which were developed into learning videos. The learning videos consist of greeting, learning objectives, content, vocabularies, conversation, and closing. The result of expert judge in media was $87.5 \%$ which was categorized as excellent material. Meanwhile, the result of material judges was $93.5 \%$ which was categorized as an excellent material. The field testing was also conducted to the students. There were $83.3 \%$ of the students strongly agreed that the language instructions used in the video were easy to understand. Based on the analysis, it can be concluded that the learning media by using PowToon can be used as teaching material in teaching English for Nurses (EFN).

\section{Suggestion}

This research is recommended to be done for the lectures and educators who teach English for Nurses subject. It is expected to apply the learning video in the classroom. Since the students use online learning nowadays, it will be better for them to get clear explanation by watching the video. For the further research, it needs to develop the effectiveness of the learning video. It can be done to know whether the learning video can improve students' achievement in learning EFN. Besides, the further researcher also can develop tutorial book for using the video. So, the lecturer will be easy to apply this learning media in teaching and learning process. 


\section{References}

Arifin R.W., Septanto, H., \& Wignyowiyoto I. (2018). Pengembangan Media Pembelajaran Berbasis Video Animasi dengan Model ADDIE dalam kegiatan Pembelajaran Learning. Information Management for Educators and Professionals, 2(2), 179-188

Awalia, I., Pamungkas, A. S., \& Alamsyah, T. P. (2019). Pengembangan Media Pembelajaran Animasi Powtoon pada Mata Pelajaran Matematika di Kelas IV SD. Jurnal Matematika Kreatif-Inovatif, 10(1), 49-56

Basriyah, K., \& Sulisworo, D. (2018) Pengembangan Video Animasi Berbasis Powtoon untuk Model Pembelajaran Flipped Classroom pada materi Termodinamika. Seminar Nasional Edusaintek. 152- 156

Budiyono, B. (2020). Inovasi Pemanfaatan Teknologi Sebagai Media Pembelajaran di Era Revolusi 4.0. Jurnal Kependidikan: Jurnal Hasil Penelitian dan Kajian Kepustakaan di Bidang Pendidikan, Pengajaran dan Pembelajaran, 6(2). 300-309. doi:https://doi.org/10.33394/jk.v6i2.2475

Daar, G.F., Ndorang, T.A., \& Golo, T. (2016). Motivasi Belajar dan Implikasinya dalam Pembelajaran Bahasa Inggris Mahasiswa Program Studi Keperawatan STIKES St. Paulus Ruteng Tahun Ajaran 2015/2016, Jurnal Wawasan Kesehatan, 1(1). 88-98

Daniati, D., Ismanto, B., \& Luhsasi, D. (2020). Upaya Peningkatan Motivasi dan Hasil Belajar Mahasiswa dengan penerapan Model Pembelajaran E-Learning Berbasis google Classroom pada Masa Pandemi Covid-19. Jurnal Kependidikan: Jurnal Hasil Penelitian dan Kajian Kepustakaan di Bidang Pendidikan, Pengajaran dan Pembelajaran, 6(3). 601-608. doi:https://doi.org/10.33394/jk.v6i3.2642

Fajar, S. (2017). Pengaruh Penggunaan Media Powtoon terhadap Hasil Belajar Siswa pata Mata Pelajaran Ilmu Pengetahuan Sosial Terpadu. Edutechnologia, 3(2), 46-57

Falahudin, I. (2014). Pemanfaatan Media dalam Pembelajaran. Jurnal Lingkar Widyaiswara, $1(4), 104-117$

Graham, B. (2015). Power Up Your Powtoon Studio Project. Birmingham: Packt Publishing. Harmer. J. (2007). The Practice of Englis Language Teaching. Pearson Longman.

Henu, N. (2017). Pengembangan Media Pembelajaran Powtoon untuk Meningkatkan Hasil Belajar Siswa Mata Pelajaran IPS Materi Penyimpangan Sosial di SMP Negeri 15 Semarang. Thesis. Fakultas Ilmu Pendidikan Universitas Negeri Semarang.

Herawati, R., Sulisworo, D., \& Fayanto, S. (2019). The Development of Learning Videos on Powtoon-based Work and Energy Topics to Support Flipped Classroom Learning. IOSR Journal of Research \& Method in Education, 9(4), 51-58

Hutchinson, T., \& Waters, A. (2008). English for Specific Purposes. Cambridge: Cambridge University Press.

Kafah, A. N. K., Nulhakim, L., \& Pamungkas, A. S. (2020). Development of Video Learning Media Based on Powtoon Application on the Concept of the Properties of Light for Elementary School Students. Gravity: Jurnal Ilmiah Penelitian dan Pembelajaran Fisika, 6(1), 34-40

Miles, M. B., \& Hubberman, M. (2014). Qualitative Data Analysis. Jakarta: Universitas Indonesia.

Nurdiansyah, E., Faisal, E. E., \& Sulkipani. (2018). Pengembangan Media Pembelajaran berbasis PowToon pada perkuliahan Pendidikan Kewarganegaraan. Jurnal Civics: Media kajian Kewarganegaraan, 15(1), 1-8

Pangestu, M. D., \& Wafa, A. A. (2018). Pengembangan Multimedia Interaktif Powtoon pada Mata Pelajaran Ekonomi Pokok Bahasan Kebijakan Moneter untuk siswa Kelas XI IPS di SMA Negeri 1 Singosari. Jurnal Pendidikan Ekonomi, 11(1), 71-79 
Puspitarini, Y. D., Akhyar, M., \& Djono. (2019). Development of Media Based on Powtoon in Social Sciences. International Journal of Educational Research Review, 4(2), 198205

Rahmah, L., Ariyanto, S., Iskandar, Z., \& Dewi, I. (2020). Development of Authentic Psychomotor Instruments for Vocational School in the Covid-19 Pandemic. Jurnal Kependidikan: Jurnal Hasil Penelitian dan Kajian Kepustakaan di Bidang Pendidikan, Pengajaran dan Pembelajaran, 6(3), 349-355. doi:https://doi.org/10.33394/jk.v6i3.2859

Rambe, N. R, \& Saragih, A. H. (2016). Pengembangan Media Pembelajaran Tenses Bahasa Inggris Berbasis Multimedia Interaktif pada Siswa Sekolah Dasar. Jurnal Teknologi Informasi dan Komunikasi dalam Pendidikan, 3(2), 181-193

Sidik, M. I., \& Winata, H. (2016). Improving Students Learning Outcomes through Application of Direct Instrcution Learning Model. Jurnal Pendidikan Manajemen Perkantoran, 1(1), 49-60

Sugiyono. (2014). Metode Penelitian Kuantitatif, Kualitatif, dan R\&D. Bandung: Alfabeta.

Tomlinson, B. (1998). Materials Development in Language Teaching. UK: Cambridge University Press. 